Анна Давлетшина

Уральский федеральный университет им. первого Президента России Б. Н. Ельцина

a.m.davletshina@urfu.ru

Anna Davletshina

Ural Federal University

a.m.davletshina@urfu.ru

\title{
ЦЕННОСТНЫЕ ОРИЕНТИАЦИИ И РЕЛИГИОЗНАЯ ВЕРА В ВОСПОМИНАНИЯХ СОВЕТСКИХ БЕЖЕНЦЕВ ВТОРОЙ МИРОВОЙ ВОЙНЫ1
}

\author{
VALUE ORIENTATIONS AND RELIGIOUS BELIEFS \\ IN THE MEMOIRS OF SOVIET REFUGEES DURING WWII
}

В статье рассматривается моральный опыт советских беженцев в ходе Второй мировой войны. Исходя из того, что моральные ценности выступают определенными смысложизненными ориентирами, которые делают человека устойчивым к потрясениям, показывается как в ситуации войны происходило переосмысление ценностей беженцами. Анализ различных эго-документов (автобиографий, личных дневников, писем) демонстрирует, что одним из ориентиров, для вынужденных покинуть свой дом из-за войны, стало осмысление через дихотомию «свой - чужой» своего морального опыта и формирование определенных ценностных ориентаций, одним из аспектов которых было обращение к вере.

Ключевые слова: православный этос, моральный опыт, ценностные ориентации, религиозная вера, беженцы, вторая мировая война.

The article focuses on the moral experience of Soviet refugees during the Second World War. We approach the ego-documents such as autobiographies, private journals, letters, memoirs with the assumption that moral values help individuals to find meaning in the events of their lives and to develop resilience to suffering and losses. We demonstrate that the refugees had to re-consider their values of the 'normal' times in order to adapt to their new status. We explore how the distinction between "us" and "them", "ours" and "theirs" became operative in structuring the moral experience of those who were forced to leave their homes because of war. We show how this distinction was variously articulated in our sources and how it transformed in cases of religious conversions.

Key words: Christian Orthodox ethos, moral experience, value orientations, religious beliefs, refugees, WWII.

1 Исследование выполнено за счёт гранта Российского научного фонда (проект №20-18-00240). 


\section{Введение}

Практически для каждого человека на бывшей советской территории опыт Второй мировой войны является частью его семейной истории, поэтому не случайно, что для российского общества тема войны занимает особое место. Память о ней не является однородной по своему содержанию: с одной стороны, в памяти семей сохраняется реальная история старшего поколения, с другой, если говорить о сохранении в коллективной памяти, то она наполнена значимыми событиями, обладающими большой ценностной нагрузкой.

В содержательном плане происходит сохранение эмоциональных воспоминаний, касающихся героических или нравственно травмирующих событий войны, как, например, сохранение памяти о блокаде Ленинграда. Вместе с этим, следует отметить, что политика памяти отличается избирательностью в плане сохранения определенных событий, которые должны выступать основанием для формирования и сохранения определенных моральных ценностей в обществе. Она носит целевой характер, чем и определяется эта избирательность: «О политике памяти мы говорим тогда, когда дело касается различных общественных практик и норм, связанных с регулированием коллективной памяти. Речь идет о коммеморации (то есть о сооружении памятников и музеев, об отмечании на государственном и местном уровне как особо значимых определенных событий прошлого), об акцентировании внимания на одних сюжетах истории и замалчивании или маргинализации других» (Миллер 2009: 6).

В России основное место занимает сохранение памяти о вкладе советского народа в победу над врагом, о подвигах и героизме советского человека на фронте и в тылу, самопожертвовании народа. Все это, как отмечает А. В. Быков, «делает историческую память о войне одним из стержней, скрепляющих общество, и важнейшим ресурсом формирования патриотических чувств» (Быков 2016: 69). Вместе с этим еще не осмыслены многие феномены Второй мировой войны, в частности, опыт советских беженцев. Как представляется, изучение опыта войны беженцев является одной из важных проблем, которую еще предстоит осмыслить для понимания войны.

Беженцы оказались в очень сложном положении, которое поставило перед ними вопрос - как в ситуации «предельности» найти в себе силы жить? Русская поэтесса Марина Цветаева вместе с другим гражданским населением Москвы в начале войны эвакуировалась в город Елабуга. Подобно многим она столкнулась с необходимостью организации жизни на новом месте: получила прописку, пыталась найти работуㄹ․ Даже стро-

2 Следует отметить, что в рассматриваемый период для того, чтобы иметь карточки на еду, обязательно нужно было где-то работать. Поэтому люди старались найти 
ила планы о том, как будет здесь жить вместе с сыном. Вроде бы можно говорить, что все хорошо и ей повезло больше, чем многим другим беженцам, но 31 августа 1941 г. она прерывает свою жизнь:

«Мурлыга! Прости меня, но дальше было бы хуже. Я тяжело больна, это уже не я. Люблю тебя безумно. Пойми, что я больше не могла жить. Передай папе и Але - если увидишь - что любила их до последней минуты и объясни, что попала в тупик» (Цветаева: http).

Острое переживание Цветаевой драмы своей личной жизни, чувство, будто она находится в жизненном «тупике» привело ее именно к такому решению дилеммы. Можно также предположить, что война в том числе повлияла на совершенный выбор. Именно поэтому осмысление опыта «бегущих» от войны, может представлять ценность для реконструирования моральных дилемм, например, смерти и жизни.

\section{Что значит «беженец»?}

Масштаб проблемы, связанный с количеством беженцев в следствие Второй мировой войны, привел к закреплению правового статуса беженца в международном праве. Вместе с юридическим определением лиц, подпадающих под статус «беженца» в соответствие с Конвенцией о статусе беженца ООН 1951 г. есть более широкое определение, из которого предлагается исходить в данном исследовании, и которое даст возможность более полно рассмотреть поставленную проблему. Что значит «беженец»? Мы будем исходить из того, что беженцы - это все лица, вынужденные мигрировать из одного места в другое в силу чрезвычайных обстоятельств (военного конфликта, стихийных бедствий, религиозных или политических гонений и т. д.). При этом беженцами в условиях войны, будем считать также тех, кто самостоятельно эвакуировался, т. к. именно они оказались «брошенными» своими, в отличие от эвакуированных с заводами, музеями и научными центрами, для которых в местах эвакуации было подготовлено все необходимое для проживания. Первые же столкнулись не только в пути, но и на местах с неготовностью в тылу их принять.

История советских беженцев в научных исследованиях является определённой «лакуной», которую еще предстоит заполнить. Советские беженцы Второй мировой войны 1939-1945 гг. больше рассматривается с экономической и демографической точки зрения, в связи с тем, что в архивах разных регионов бывшего Советского Союза сохранились документы о количестве эвакуированных в разное время и об организа-

хоть какую-нибудь работу. Так и М. Цветаева, по воспоминаниям А. Цветаевой, готова была пойти мыть посуду в столовой, которую должны были открыть, и даже написала об этом записку (Цветаева А. 2005). 
ции и оказании им помощи (но опять же, не по всем областям были проведены такие исследования) (Куманев 2006). Следует отметить, что имеющаяся информация не дает возможность восстановить полную картину событий, в связи с тем, что помимо организованных эвакуаций, которые можно как-то зафиксировать, было очень много неорганизованных миграций внутри страны.

Здесь нас будут интересовать преимущественно личные воспоминания беженцев как отражение морального опыта, а не статистические данные. Дневниковые записи - очевидцев и непосредственных участников событий - представляют особую ценность. К сожалению, этот вид исторических источников крайне малочислен в сравнении с большим количеством опубликованных официальных документов. Представляется, что именно эго-документы несут в себе уникальную информацию о повседневной жизни людей на фронте и в тылу, дают возможность увидеть события прошлого глазами «простого» человека. Особенно сложно в этом плане с воспоминаниями беженцев и эвакуированных. Возможно, это связано с тем, что, во-первых, по большей части, беженцами были женщины, дети и пожилые люди и мало кто из них фиксировал в записях происходящее вокруг. В период самой войны важнее было решить вопросы, связанные с выживанием - определиться с местом проживания, обеспечить себя и близких едой, трудоустроиться и определить детей в детские сады и школы и т. д. Во-вторых, в военный и послевоенный период в пропагандистских целях больше собирались и публиковались письма и воспоминания фронтовиков и тех, кто, непосредственно, воевал, а не «бежал» от войны. Жертвы среди гражданского населения и потоки беженцев, были чем-то вроде фона войны и не всегда осознавалась ценность их воспоминаний для будущих поколений.

Представляется важным показать, что, оказываясь на пределе своих возможностей и сил, на границе жизни и смерти, естественным образом они начинали задумываться о том, как остаться человеком и как сохранить веру в других людей. Поэтому интерес представляют воспоминания о первых годах войны, когда беженцы столкнулись с наибольшими трудностями, носящими как физический, так и духовный характер. Лишь за первые полгода войны в 1941 году из центральной части России, Украины и Белоруссии в глубь страны на восток по разным подсчетам устремилось более 10 миллионов беженцев и эвакуированных, а в первой половине 1942 года еще около 1,5 миллионов. В связи с тем, что значительное количество эвакуированных было из центральной части, районов, которые исторически считались православными, можно увидеть в моральном опыте беженцев религиозные мотивы, ставшие в том числе основой некоторых ценностных ориентаций человека во время войны. 


\section{Опыт «неопределенности» и «брошенности» в воспоминаниях беженцев}

В ситуации войны беженцы в спешке покидали свои дома, нередко оставляли своих родных и близких, спасаясь от смерти. В воспоминаниях очевидцев войны достаточно часто можно увидеть описание идущих по дорогам беженцев - голодных, измученных, с застывшей тревогой в глазах. Например, Иосиф Уткин, советский поэт, встретив беженцев в 1941 г. на дороге в Сумской области, отметил удивительное спокойствие, «отсутствие слёз в их глазах» (Рахтанов 1947: 172), видимо связанное с верой в то, что скоро можно будет остановиться в этом пути. Беженцы на самом деле вне зависимости от ситуации верили, что они покидают свои дома временно, что в другом городе они будут находиться не долго - один или два месяца — а после вернутся домой.

Это вера очень хорошо видна в воспоминаниях Елены Алексеевой, как их семья покидала родные места. Она вспоминает, что ее бабушка начала заранее готовиться к тому, что возможно им придется бежать, если немецкие войска подойдут близко к их поселку. Важно было «схоронить» ценные вещи до их возвращения, а также подготовить сумки с вещами и продуктами, которые понадобятся в дороге:

«Когда началась война, и немец подходил к Калинину, <бабушка> начала готовиться к эвакуации: выкопала яму в сарае для вещей, сшила заплечные мешки для себя, матери моей и меня, запасла мед, сухари и другие продукты. Но все произошло так внезапно, что бежали, ничего не спрятав. Утром, тепло еще было, в платьях ходили (октябрь), прибежала Настина мать (Настя - жена моего дяди Анатолия) и закричала: “Надежда Федоровна, немцы в город входят!"» (Алексеева 2016: 26).

Но даже если у людей было время подготовиться к эвакуации из мест, куда пришла война, ее приход всегда был неожиданностью. Все равно бежали спешно, не успевая что-либо спрятать или беря вещи, которые были «лишними»:

«И вот пришла пора «бежать» по-настоящему. Когда Настина мать закричала, бабушка сунула мне узелок с ложками и вилками из мельхиора и велела бросить в яму. Я бросила узелок, а Настина мать свой чемодан и, не дождавшись еще вещей, быстро закопала яму. Так спрятать ничего и не удалось. Надели на плечи мешки и «побежали» из города - пошли пешком. Все улицы были запружены идущим народом. Особенный поток был на Волжском мосту. Очень хорошо помню, что ехали по нему и грузовики, в одном был большой фикус. Они никого не подсаживали» (Там же: 26).

Также Алексеева пишет в воспоминаниях, что как только ее бабушка услышала «об изгнании немцев», она поспешила вернуть назад и удостоверившись, что дом цел вернулась за ней и ее мамой, чтобы привезти их домой и «налаживать жизнь». 
Эта вера в скорое возвращение и «теплый» образ дома дополнительно закреплялся в памяти людей реальностью, с которой они столкнулись в пути к местам эвакуации и временного, как они считали, места проживания. В многодневных пеших переходах или переездах в «товарняках», не подготовленных для перевозки людей, они столкнулись с физическими лишениями - голодом, болезнями, нищетой:

«В эвакуации есть было нечего, вещи из заплечных мешков быстро обменяли на еду, а потом просили под окнами корочку хлебца. Один день только помню сытный: в колхозе зарезали корову, в печке русской протопили кишки и напекли ржаных шанег с картошкой. Все это время и потом бабушка не падала духом, успевала смотреть за больной матерью и за мной. Удивительная душевная стойкость, чтобы выжить. Где-то добывала мерзлую картошку ... Весной 1942 г. стала сажать картофельные глазки» (Там же: 27).

В дороге их путь пролегал через бомбежки и обстрелы, в связи с чем многие гибли, так и не добравшись до безопасного места. Они постоянно находились в состоянии тревоги и страха, не зная, что позади них - близко ли враг, защитит ли их Красная армия — и что впереди не попадут ли они в еще более страшное место, найдут ли они сострадание среди людей, кров и еду. К сожалению, ощущение полной неопределённости в будущем и «брошенности» подтверждалось опытом беженцев. Еще при попытке добраться до места, беженец сталкивается с тем, что он не «виден» на этой войне:

«Поездом нельзя, не дают билетов, а если дают, все равно не пускают в вагоны, которые переполнены военными и командировочными. А если и пускают иногда на часок, перед отправкой поезда высаживают для того, чтобы разместить вновь прибывших командировочных. Машины, грузовики берут обывателя в качестве зайца, и нельзя ручаться, что не высадят его в Подольске. При этом необходимо запастись махоркой, чтобы шофер грузовика согласился взять пассажира на свою машину» (Малахиева-Мирович 13 апреля 1942 г.: http).

Где-то они находили помощь у местного населения. Например, в Костроме для них собирали детскую одежду, игрушки для организуемых детских домов, круглосуточно дежурили в эвакуационных пунктах, помогая выдавать талоны, чтобы хоть как-то облегчить их страдания. Но вместе с этим они сталкивались с циничным отношением к их ситуации. Также в Костроме были те, кто предпочитали не сдавать в данные пункты товары для беженцев, а продавать их торговым и промышленным предприятиям, также были случаи спекуляции жилой площадью (В грозном 41-м... 2001: 44).

Беженцы столкнулись с тем, что оказывается сострадание и помощь ближнему не является чем-то само собой разумеющимся. Правило «сам погибай, а товарища выручай!» не относилось к ним и это было страш- 
ным осознанием. Сама мысль о том, что русский человек не поможет в беде другому, воспринималась как неправда. Тем более сложно было поверить в то, что это реально. Но мемуары русской поэтессы Варвары Малахиевой-Миронович, которая была вынуждена спешно эвакуироваться из Москвы в первые годы войны, показывает реальность и крах веры в сострадание и сомнения в помощи от «своих»:

«“Погибаю, погибаю!”- врывается в сонное сознание вопль ростовской беженки - учительницы. Сразу отхлынул сон. Включаю свет. Жуткой показалась непроглядная темнота. Точно не в стенах моей комнаты она, а среди разбушевавшегося моря, где со всех сторон барахтаются и тонут потерпевшие крушение люди. .... Она остановила меня в нашем переулке и стала излагать свое беженское «хождение по мукам». Все было как у всех беженцев - истрачены деньги, распроданы за бесценок вещи, нет крова, нет пищи. Чужой город. Я посоветовала ей обратиться в Наркомпрос. Что еще могла я сделать? Я сама беженец, чудом держащийся на гребне волны...» (Малахиева-Мирович 15-17 сентября 1942 г.: http).

Сложность положения беженцев состояла в том, что их никто не ждал, особенно в первые годы войны. Города не были готовы принимать большие группы эвакуированных из мест сражений и тем более на длительный срок. Вместе с этим они сталкивались с тем, что в получении минимальной помощи, после холода и голода в дороге, им могли отказать, т. к. нет документов, нет работы, а значит и нет и «жилплощади». Сталкиваясь с этим равнодушием к их горю со стороны системы, они надеялись найти сострадание хотя бы от таких же советских людей, как они - просто, чтобы почувствовать — что они люди и их жизнь имеет ценность. Это ощущение неопределенности, смешенное с чувством «брошенности», нахождения вне советского общества, привело к попытке осмысления привычных ценностей.

\section{Дихотомия «свой - чужой» в формировании ценностных ориентаций}

В нечеловеческой ситуации беженцы оказались перед сложной моральной дилеммой, подвергнувшей сомнению их иерархию ценностей - где «свои», а где «чужие»? Это не является случайным, т. к. дихотомия «свой — чужой» является основополагающей для человеческой культуры. Человек всегда осознает себя как часть какой-либо общности и противопоставляет другим. В этом противопоставлении происходит формирование собственной идентичности и ценностного отношения к миру.

Особенно важно определить «своих» и «чужих» оказалось во время войны, т. к. от этого зависела собственная жизнь. Казалось бы, здесь не должно возникать сложности, ведь «чужой» — это враг. Он разрушает 
города, он обстреливает дороги, не давая уйти в тыл к своим. Именно с ним ушли воевать твои близкие - отцы, мужья и сыновья. «Свой» это любой советский человек. Он всегда поддержит тебя, отдаст все, но тебя не бросит. Но воспоминания беженцев показывают, что здесь они столкнулись с относительностью границ «свои» и «чужие», когда «чужой» — немец, враг — оказывает сострадание, а «свой» — боец Красной Армии, друг — бросает тебя:

«Ты писала, то когда выезжали, так вас напугали тем, что у вас все отберут. Как же у вас хватало совести слушать такую брехню и не плюнуть в рожу той сволочи, которая ее распространяла. Кто же, по-вашему, в нашей армии? Неужели, одев военную форму, мы стали чужими вам и вы нам больше не доверяете? А как же вы могли верить тем зверям, с которыми мы находимся в безумной схватке, которые прославили себя на весь мир небывалами кровавыми делами? Я не могу понять этого, и это меня тем более оскорбляет и с твоей и с маминой стороны» (XX век: письма войны 2016: 575).

Осознание этой реальности было сложным для всех — и особенно сложно было найти доводы для оправдания «наших», найти в себе моральные силы, чтобы вновь назвать их «своими». А. Николаев, пытаясь объяснить родным, что они не должны бояться своей армии и должны поехать в советский тыл, апеллирует к тому, что «наша армия» не может отдать «врагу» «наши русские места»:

«Я видел много эвакуированных, многим помогал эвакуироваться, и ни одного слова плохого о нашем к ним отношении не слыхал. Я слышал горькие слова упрека за наше отступление. За то, что оставляли врагу наши русские места. Эти слова были правдивы и острыми ножами резали на части наши сердца. Нам и самим нелегко было отходить, видя бросающие нам вслед скорбные взгляды оставляемых без защиты наших людей. Мы всеми силами старались помочь тем, кто уходил из наших родных мест в глубокий советский тыл, и как самой большой радости ждали приказом на наступление, чтобы вырвать из вражеских лап оставленных при отступлении наших советских людей» (ХХ век: письма войны 2016: 576).

Да, не всегда есть возможность дать отпор врагу и не допустить разрушение «родных мест». Но это связано не с тем, что судьба простых людей в этой насильственной войне никого не волнует. Отступление болезненно для отступающих войск также как и для покинутых. В этой моральной аргументации он обращается к укорененной в русской православной культуре мысли - русские не оставляют своих родных в беде и не отдают врагу русские места. Это должно стать основанием для морального оправдания поступков наших и придать веру.

Пытаясь выжить, сомневаясь, что «свои» проявят сострадание и помогут, беженцы оставались на едине с собой и начинали искать опору внутри себя самих, которая часто принимала религиозный характер. Это 
связано с тем, что в неопределенной ситуации человек демонстрирует религиозное отношение к реальности, вызванное желанием как-то осознать и принять «нереальность» происходящего. Воспоминания участников и очевидцев войны демонстрирует, что, в частности, такой попыткой становится обращение через веру к Богу. Много подобных воспоминаний у непосредственных участников военных действий - солдат. Например, один из них, вспоминая войну рассказывает:

«Когда лежишь под обстрелом и прижимаешься к матери-земле, а на тебя с воем летят снаряды, и любой может угодить по тебе, то, кто бы ты ни был, ты вспоминаешь Господа» (Хаджебиекова 2014: 2).

Ведь на войне, которая так абсурдна, в любую минуту можно расстаться с жизнью и предстать перед Богом:

«Канонада и танки и грохот сражения, от которого я чуть не сошла с ума в эту ночь и не знала, куда деваться днем, заглушены этим миром. Дана передышка - отвернуться от неправдоподобного ужаса войны, почувствовать его преходящесть, может быть иллюзорность - и уловить над ним дыхание жизни в ее целом и высшую волю и высший смысл во всем, что совершается в человеческой истории и в жизни каждого отдельного человека.

Что во всякой войне непереносимо страшно? Не страдания людей, не гибель их, не разрушение их жилищ, их быта. Страшен дух убийства, овладевший волей народов и их вождей. Поэтому другие гибельные катастрофы - крушения поездов, землетрясения, пожары, наводнения, ураганы - не кроют в себе того потрясающего до ужаса, как война» (Малахиева-Мирович 1 июля 1941 г.: http).

Рефлексируя над тем, почему «дух убийства» восторжествовал, отчего не прекращаются бомбежки, человек уже не может быть на стороне определенного народа или вождя. В этой ситуации тяжело верить и идти вперед под лозунг «За Родину, за Сталина!». Возникает только один вопрос - «Господи, за что нам эти мучения?». В чем твоя «высшая воля» и «высший замысел» происходящего?

««Хлеб наш насущный даждь нам днесь» - расширять и усложнять эту молитву в такую годину, как наша, - кощунственно. Когда стояла в райсобесе за распределением пенсионерской очереди (и в количестве целого кило), эта смиренная и тревожная дума о хлебе и мольба, обращенная к пухлому, алкоголичному председателю, была почти на всех лицах» (Там же: http).

Диалог с Богом, вера в то, что он все же сбережет тебя на войне, становится для беженцев тем, что помогает выдержать страдания и сохранить надежду. Причитая, человек как бы смиряется с ситуацией и находит в себе силы жить дальше, преодолевая чувство отчаяния в сложившейся ситуации: 
«Все чаще останавливаемся и отдыхаем, мама на остановках причитает: - Ох, и дорога!.. И все равно вечность этой дороги не такое уж божье наказание, ежели позади годы никудышней судьбы. За что Он посылает нам такое: в Курской области — голод, а тутака — война! Разлучил с отцом и мужем!.. Удел нам ныне - терпеть!.. Кто малым доволен, тот у Бога не забыт. Господи Иисусе Христе, сын Божий, помилуй нас грешных!» (Овсянников 2014: 491).

\section{Выводы}

Персональный опыт войны беженцев является одной из тем, которую еще предстоит осмыслить для понимания войны, которая переживалась как экзистенциальная. Анализ различных эго-документов людей, вынужденных «бежать» от войны в тыл, показал, что особенно «болезненными» стали даже не физические лишения, но ощущение «брошенности» своими же в ситуации войны. Этот специфический моральный опыт привел к проявлению религиозного отношения к окружающей реальности, через которое человек пытался морально оправдать происходящее и найти внутренние силы для жизни — как от осуждения можно прийти к оправданию поступков «наших», как оставаться нравственным и сохранять веру и надежду, когда общество не проявляет сострадание и «вытесняет» за свои пределы.

\section{ЛИТЕРАТУРА}

12 января 1943 г., А. Николаев. ХХ век: письма войны:: антология военной корреспонденции. Москва: Новое литературное обозрение, 2016: 575-576.

Алексеева Елена, Алексеев Алексей, Алексеев Владимир. «Бабушка (фрагмент воспоминаний о войне)». Каждому поколению - своя победа. Ижевск: Иднакар, 2016: $23-29$.

Быков А. В. «Историческая память о Великой отечественной войне и современная политика». Вестник Омского университета. Серия «Исторические науки» 10/2 (2016): 66-70.

В грозном 41-м...: Сб. док. и материалов: 22 июня - 31 дек. 1941 г.: (К 60-летию начала Великой Отечеств. войны 1941-1945 г2.). Кострома, 2001.

Куманев Георгий. «Война и эвакуация в СССР. 1941-1942 гг.». Новая и новейшая история 6 (2006): 7-27.

Малахиева-Мирович Варвара. «1 июля 1941 г.». Корпус личныхх дневников «Прожито». URL: https://prozhito.org/note/255793.

Малахиева-Мирович Варвара. «13 апреля 1942 г.». Корпус личных дневников «Прожито». URL: https://prozhito.org/note/255827.

Малахиева-Мирович Варвара. «15-17 сентября 1942 г.». Корпус личных дневников «Прожито». URL: https://prozhito.org/note/255851.

Миллер Алексей. «Россия: власть и история». Pro et Contra 46/3-4 (2009): 6-23.

Овсянников Юрий. «Воспоминания о поворотах судьбы в житейском море. Рассказ первый. Беженцы». Лингвистика. Семиотика. Метапоэтика. Ставрополь: Издательство Северо-Кавказского федерального университета — «Дизайн-студия Б», 14/1 (2014): 487-502. 
Рахтанов Исай. «Военной дорогой». Новыци мир 5 (1947): 171-174.

Хаджебиекова Ирина. «Христиане во время Великой Отечественной войны». Христианская газета 24.04.2014: 2.

Цветаева Анастасия. Воспоминания. Москва: Издательский дом «Журналист», 2005.

«Цветаева Марина Ивановна. Эфрону Г. С., 31 августа 1941 г.» URL: http://tsvetaeva.litinfo.ru/tsvetaeva/pisma/letter-1091.htm

\section{LITERATURE}

12 yanvarya 1943 g., A. Nikolaev. XX vek: pis'ma vojny: antologiya voennoj korrespondencii. Moskva: Novoe literaturnoe obozrenie, 2016: 575-576.

Alekseeva Elena, Alekseev Aleksej, Alekseev Vladimir. «Babushka (fragment vospominanij o vojne)». Kazhdomu pokoleniyu - svoya pobeda. Izhevsk: Idnakar, 2016: 23-29.

Bykov A. V. «Istoricheskaya pamyat' o Velikoj otechestvennoj vojne i sovremennaya politika». Vestnik Omskogo universiteta. Seriya «Istoricheskie nauki» 10/2 (2016): 66-70.

Cvetaeva Anastasiya. Vospominaniya. Moskva: Izdatel'skij dom «Zhurnalist», 2005.

«Cvetaeva Marina Ivanovna. Efronu G. S., 31 avgusta 1941 g.» URL: http://tsvetaeva.lit-info. $\mathrm{ru} /$ tsvetaeva/pisma/letter-1091.htm

Kumanev Georgij. «Vojna i evakuaciya v SSSR. 1941-1942 gg.». Novaya i novejshaya istoriya 6 (2006): 7-27.

Malahieva-Mirovich Varvara. «1 iyulya 1941 g.». Korpus lichnyh dnevnikov «Prozhito». URL: https://prozhito.org/note/255793.

Malahieva-Mirovich Varvara. «13 aprelya 1942 g.». Korpus lichnyh dnevnikov «Prozhito». URL: https://prozhito.org/note/255827.

Malahieva-Mirovich Varvara. «15-17 sentyabrya 1942 g.». Korpus lichnyh dnevnikov «Prozhito». URL: https://prozhito.org/note/255851.

Miller Aleksej. «Rossiya: vlast' i istoriya». Pro et Contra 46/3-4 (2009): 6-23.

Ovsyannikov Yurij. «Vospominaniya o povorotah sud'by v zhitejskom more. Rasskaz pervyj. Bezhency». Lingvistika. Semiotika. Metapoetika. Stavropol': Izdatel'stvo SeveroKavkazskogo federal'nogo universiteta — «Dizajn-studiya B», 14/1 (2014): 487-502.

Rahtanov Isaj. «Voennoj dorogoj». Novyj mir 5 (1947): 171-174.

Hadzhebiekova Irina. «Hristiane vo vremya Velikoj Otechestvennoj vojny». Hristianskaya gazeta 24.04.2014: 2.

V groznom 41-m...: Sb. dok. i materialov: 22 iyunya - 31 dek. 1941 g.: (K 60-letiyu nachala Velikoj Otechestv. vojny 1941-1945 gg.). Kostroma, 2001.

Ана Давлетшина

\section{ВРЕДНОСНА УСМЕРЕЬА И РЕЛИГИОЗНА ВЕРА У УСПОМЕНАМА СОВЈЕТ- СКИХ ИЗБЕГЛИЦА У ДРУГОМ СВЕТСКОМ РАТУ}

\section{Резиме}

У раду се сагледава морално искуство совјетских избеглица током Другог светског рата. Полазећи од становишта да су моралне вредности својеврстан фундус смисла и живота, који чини човека отпорним на потресе, показује се како су избеглице у ратним условима преосмишљавале вредности.

Демонстрира се искуство људи примораних да „беже“ од рата у позадину, које постаје „болно“ не само због претрпљених физичких траума, већ и услед осећаја да су их најближи „напустили“. Анализа различитих его-докумената (аутобиографије, лични дневници, писма) показује да је преко дихотомије „свој-туђи“ дошло до осмишљавања 
стеченог искуства и до формирања одређених вредносних оријентација. Ово пак морално искуство довело је до испољавања религиозног односа према средини, преко којег је човек покушавао морално да оправда оно што се догађало и да пронађе унутрашњу снагу за даљи живот - како од осуде доћи до оправдања поступака „наших“, како остати моралан и сачувати веру и наду, када друштво не испољава сажаљење и „одбацује“ те изван својих граница.

Кључне речи: православни етос, морално искуство, вредносна оријентација, религиозна вера, избеглице, други светски рат. 